\title{
Councils, Counsel and Consensus in Henry VIII's Reformation
}

\section{RICHARD REX}

The one who really loves his prince is the one who counsels him and urges those things through which his rule is loved, his good name safeguarded, and his conscience unharmed. ${ }^{1}$

Even before Elton's Tudor Revolution in Government (1953) it was recognised that the reign of Henry VIII represented a crucial stage in the development of the royal council, most notably in the formal emergence of a privy council unburdened by the judicial functions that had long clung to the king's council thanks to its role at the centre of the royal court. The privy council that achieved autonomous existence in 1540 no longer bore even the outward form of a judicial body, unlike most other government departments of that time. Unlike most of the others, it was not even called a court. Its fundamental role, of course, was executive, something which many of Elton's successors found it hard to appreciate as it was always so tempting to see the privy council in terms of the mid-twentieth-century high tide of British cabinet government. But the desire to see the privy council as a consultative policy-making body was not wholly without foundation. However unrealistically, Tudor political culture

\footnotetext{
${ }^{1}$ [Stephen Baron], De Regimine Principum ad Serenissimum Regem Anglie Henricum Octauum (London, Wynkyn de Worde, n.d. [c.1509)]), sig. B5r: 'Ille realiter diligit principem suum qui sibi consulit et optat illa per que eius dominium diligitur, eius fama custoditur, eius conscientia non leditur'.
} 
imagined royal councils in terms of counsel or consultation. For our purposes the key to getting council and counsel in perspective is to realise that while in its formal manifestations as a group of men meeting around a table and keeping minutes of their decisions, the privy council was an executive or administrative body, the privy councillors themselves were the men to whom the monarch would mostly turn for advice and discussion, albeit usually in more informal contexts.

Thanks above all to Elton and Guy, the process by which the privy council burst out of the chrysalis of the king's council is now clearly understood, and need not be recapitulated here. $^{2}$ It is merely useful to note that the institution visible at moments during the Cromwellian decade, ${ }^{3}$ and formally established in 1540 , had already been sketched out in

${ }^{2}$ G. R. Elton, The Tudor Revolution in Government (Cambridge, Cambridge University Press, 1953), ch. V, 'The Privy Council', pp. 316-69. But note also the important contribution, just before Elton, of W. H. Dunham, ‘The Members of Henry VIII's Whole Council, 1509-1527', English Historical Review, 59 (1944), 187-210; John Guy, 'The King's Council and Political Participation', in A. Fox and J. Guy, Reassessing the Henrician Age (Oxford, Blackwell, 1986); and 'The Privy Council: Revolution or Evolution?', in C. Coleman and D. Starkey (eds), Revolution Reassessed (Oxford, Clarendon, 1986). More recently, see Steven Gunn, 'Conseils et conseillers en Angleterre sous les premiers Tudors (1485-1558)', in C. Michon (ed.), Conseils et conseillers dans l'Europe de la Renaissance, v. 1450-v.1550 (Rennes, Presses universitaires de Rennes, 2012); see also Watts's contribution to this volume.

${ }^{3}$ See C. S. L. Davies, 'The Cromwellian Decade: Authority and Consent', Transactions of the Royal Historical Society, 6th ser., 7 (1997), 177-95. Davies emphasises the importance of the rhetoric of consent in the politics of the 1530s, even as he highlights the gulf between that rhetoric and the reality of coercion. 
Wolsey's Eltham Ordinances in 1526; and that both Wolsey and Cromwell had ulterior motives in providing a clearer definition of the council's traditional inner ring. It is helpful to realise that Henry himself had a clear sense that there were different levels within his council. Early in 1532, he referred to 'our privy council' and 'our secret council', distinguishing that group from 'our grand council'. ${ }^{4}$ Not only the terms he used but also the context seem to indicate something more than the mere 'council attendant on the king' that Elton acknowledged as a regular feature of medieval royal government, though of course they also reflect contemporary French usage, where 'conseil étroit' and 'conseil privé' were common currency by the reign of François I. ${ }^{5}$

The focus of this paper is on Henry's conception and utilisation of counsel and councils in the early 1530s, though it will draw in evidence from elsewhere in the reign at some points. The theory of counsel remained much the same, whether discusssed with the naïve moralism of Stephen Baron in his sermon on princely government (cited at the head of this chapter), the subtle irony of More in Utopia or the satirical barbs of Thomas Elyot in Pasquil

\footnotetext{
${ }^{4}$ Henry VIII to Gardiner, 16 February 1532, in Records of the Reformation, ed. N. Pocock, 2 vols (Oxford, Clarendon, 1870), II, 190-206, at 193. Carlo Capello wrote of the 'Conseio secreto dil Re', although it is not clear whether he meant the council or the House of Lords. See Capello to the Signoria, 20 March 1532, Calendar of State Papers Venetian (henceforth CSPV), IV, 1527-33, no. 753, pp. 329-30, at p. 330.
}

${ }^{5}$ Elton, Tudor Revolution, pp. 322, 332. Elton tends to heighten the differences, rather than the continuities, between the formal privy council after 1540 and conciliar entities prior to that, as also to minimise the role of Henry VIII in bringing about change. For the French council, see R. J. Knecht, Francis I (Cambridge, Cambridge University Press, 1982), pp. 212; or, for a deeper analyis, Cédric Michon (ed.), Les conseillers de François $1^{\text {er }}$ (Rennes, Presses universitaires de Rennes, 2011). 
the Playne. But the interplay of that theory with practical politics and personal interests altered dramatically, like so much else, in the crucible of the divorce, of Henry VIII's long struggle to rid himself of his first wife, Catherine of Aragon, in order to marry his lover, Anne Boleyn. ${ }^{6}$ In particular, this paper suggests that in the aftermath of Wolsey's fall there was a brief but discernible revival of the informal medieval tradition of the 'great council' as Henry strove to navigate the choppy political waters that his pursuit of a divorce had stirred up. It argues that Henry had an impressive grasp of the theory of good counsel, but that his conciliar practice in the 1530s was more about his efforts to influence the minds of his subjects than about their efforts to influence his. The councils of the early 1530s were very much directed towards consensus-building, and as that consensus was put together, Henry's avowed and theoretically pure openness to good counsel gave way to an increasingly hostile reaction to any advice which ran contrary to his express will and desire. The outward face of free counsel remained on show, but the reality was attenuated, though never completely eliminated.

The fall of Wolsey in autumn 1529 brought to an end a period during which the king's council had been very much on the back seat. For years the despatches of ambassadors had spoken almost exclusively of king and cardinal. The council had been operative, but largely in its judicial capacity and in any case under Wolsey's close control. ${ }^{7}$ A more political

\footnotetext{
${ }^{6}$ In medieval Latin Christianity, 'divorce' as understood today was simply not possible.
} Henry sought what would today be called an 'annulment', that is, a judicial declaration that a supposed marriage had not been validly contracted. The term annulment is, paradoxically, both more accurate and anachronistic, for the sources of Henry's own time generally refer to what he sought as a 'divorce'. For convenience, that usage is followed here.

${ }^{7}$ For the etiolated political role of the council under Wolsey, see J. Guy, 'Wolsey and the Tudor Polity', in S. J. Gunn and P. G. Lindley (eds), Cardinal Wolsey: Church, State, and Art 
council occasionally came into view, as in 1525 , when the imperial ambassador, Louis de Praet, ill-advisedly sent a despatch to his master which was larded with unguarded observations about Wolsey's political dominance. His messenger was detained as a suspicious character in the course of a 'privye watche' on London and its suburbs, and was brought before Thomas More, who read the letter and promptly presented it (not, perhaps, without a certain sense of mischief) to Wolsey. The outcome was that Louis de Praet was summoned before Wolsey to receive a brutal dressing-down in the presence of as full a royal council as could be gathered, replete with high officers of the Crown, courtiers and peers. ${ }^{8}$ Ironically, of course, the presence of the council in this case was entirely decorative, a façade put up to disguise the truth to which the ambassador had so unwisely adverted. Revealingly, in relating the episode to Richard Sampson (resident ambassador at Charles V's court), Wolsey noted that those in attendance included Norfolk, the Marquess of Exeter, Cuthbert Tunstall, Sir Richard Wingfield 'and other of the Kinges Privey Counsail, of whom many had herde my conference the day bifore with the said Ambassadour'. The councillors had 'herde my conference': it was Wolsey's business, and they had no active role in it. ${ }^{9}$

(Cambridge, Cambridge University Press, 1991), esp. pp. 56-65. See also Elton, Tudor Revolution, pp. 61-5. For the busier judicial side to conciliar business under Wolsey, see Guy, 'Privy Council: Revolution or Evolution?', pp. 65-7.

${ }^{8}$ Cardinal Wolsey to Richard Sampson, 13 February 1525, State Papers ... Henry the Eighth, 11 vols (London, Record Commission, 1830-52), VI, 386-402, esp. 391, 394-7.

${ }^{9}$ Wolsey to Sampson, State Papers, VI, 394. As Elton notes (Tudor Revolution, p. 64), the political role even of the council attendant under Wolsey was simply to proffer 'ready endorsement of what he put before them'. In the terms of Wodehouse's classic analysis of Hollywood motion-picture conferences, they were 'Nodders'. P. G. Wodehouse, Blandings Castle and Elsewhere (London, Herbert Jenkins, 1935), p. 222. 
What brought Wolsey's hegemony to an end was the ignominious collapse of the public tribunal he convened with his fellow cardinal, Lorenzo Campeggio, at the London Blackfriars in summer 1529. The tribunal had been intended and expected to annul Henry's first marriage, but it broke up in disarray as the tides of Italian politics flowed strongly in favour of the Emperor Charles V, nephew to Catherine of Aragon. ${ }^{10}$ The dismissal of Wolsey entailed a repudiation of his entire regime, including his cavalier disregard of the king's council. ${ }^{11}$ The most visible impact of this for our purposes was a sharp resurgence in the language of counsel. For if there was one thing Henry desperately wanted in the aftermath of Blackfriars it was good advice: advice that would help him get his way. After Wolsey's fall, ambassadors refer easily and often to council and councillors, even while agreeing that Henry had taken personal control of government. It was, reported the Venetian ambassador, the king's council that packed off Wolsey to internal exile at York. ${ }^{12}$ Henry himself was keen to govern by counsel, and to be seen to be doing so. The selection of Thomas More as the new chancellor in autumn 1529, on the advice of the council, was a plain signal of Henry's intentions. ${ }^{13}$ No Englishman had better theoretical credentials as a councillor than the author

${ }^{10}$ The best account of the Blackfriars tribunal is found in H. A. Kelly, The Matrimonial Trials of Henry VIII (Stanford, Stanford University Press, 1976), chs. 4-6.

${ }^{11}$ E. W. Ives, 'The Fall of Wolsey', in Gunn \& Lindley (eds), Cardinal Wolsey. For the charges relating to Wolsey's disregard of the council, see A. F. Pollard, Wolsey (London, Longmans, 1929), p. 260.

${ }^{12}$ Ludovico Falier to the Signoria, 2 March 1530, CSPV, IV, 1527-33, no. 565, p. 239. ${ }^{13}$ Pollard, Wolsey, p. 255. J. C. Warner has aptly emphasised the king's evident desire to stand before the world as a well-counselled monarch. This is one of the main themes of his Henry VIII's Divorce: Literature and the Politics of the Printing Press (Woodbridge, Boydell, 1998), at e.g. pp. 3, 16, 49, 55, and passim. 
of Utopia (1516), the instant classic of political thought which included a lengthy consideration of the art of counsel. ${ }^{14}$ Moreover, as F. W. Conrad has shown, friendship was considered a defining element in good counsel. Councillors ought to be friends, true friends, to their prince - friends, that is, in the full Ciceronian sense, in a complete harmony of shared values and mutual respect as well as affection. And More was known to be the king's friend. ${ }^{15}$ Henry was also keen that everyone should appreciate the change in the political and conciliar climate. When Brian Tuke, a royal official and councillor who often performed secretarial duties, told the still new imperial ambassador, Eustace Chapuys, about the king's new political resolutions in early 1530 , he was clearly passing on a prepared message. The king, he said, 'had determined to take the management of his own affairs and had appointed several councillors in order not to be without a council when the duke of Norfolk, the Chancellor, and others are detained here [in London] by their official duties' ${ }^{16}$

For Chapuys, always a hostile observer, but none the less penetrating for that, the king's avowed openness to counsel was an empty pretence from the start. Absolutely committed to Catherine of Aragon's cause, and convinced (probably rightly, at least at that time) of the

${ }^{14}$ The starting-point for scholarly discussion of Utopia as a meditation on counsel remains $\mathrm{J}$. H. Hexter, More's Utopia: The Biography of an Idea (Princeton, Princeton University Press, 1952), esp. pp. 103-15.

${ }^{15}$ F. W. Conrad, 'The Problem of Counsel Reconsidered: The Case of Sir Thomas Elyot', in P. A. Fideler and T. F. Mayer (eds), Political Thought and the Tudor Commonwealth (London, Routledge, 1992), pp. 76-9.

${ }^{16}$ Chapuys to Charles V, 6 February 1530, Calendar of State Papers Spanish (henceforth CSPSp), IV, part i, 1529-30, no. 257, pp. 446-53, at p. 451. See also Scarpinello to the Duke of Milan, 15 August 1530, CSPV, IV, 1527-33, no. 601, p. 252, noting that Henry 'chooses to know and superintend everything himself’ 
extent of noble and popular support for the queen throughout England, Chapuys told the king to his face on Easter Monday 1530 that he was out of touch with his own people. Henry's immediate rejoinder, that he was 'accessible to all and ready to listen to everyone and seek for information', should probably not be dismissed quite so cavalierly as it was by the ambassador. ${ }^{17}$ At the very least Henry wanted what he said to be true, and the fact that he seems to have listened to the ambassador's strictures without losing his temper shows that he was still capable of listening to unwelcome advice. ${ }^{18}$ The reply also shows that he was well versed in the theory of counsel. But he also knew that even according to the most sophisticated theories of counsel, while it was his obligation to listen to advice, it was his prerogative to decide whether or not to follow it. According to the French ambassador Jean de Dinteville, late in 1533, 'he says that he is not governed by, but governs, his Council; otherwise the Council would be King, and not he. He desires their opinions, but decides for himself, as every King ought to do. ${ }^{19}$

${ }^{17}$ Chapuys to Charles V, 23 April 1530, CSPSp, IV.i, no 290, pp. 503-15, at pp. 505-6. Neither, one might add, should the reports of Chapuys be dismissed cavalierly. Ambassadorial despatches should be read cautiously; but ambassadors must be assessed as individuals, and their reports, in whole and in part, considered in their particulars rather than as a genre. Chapuys writes unusually detailed despatches, and gives every indication of taking great pains to secure up-to-date and accurate information.

${ }^{18}$ Likewise, Warner suggests, Henry's choice of More as Chancellor reflected his concern with appearing to be open to critical counsel (Henry VIII's Divorce, p. 55).

${ }^{19}$ Memorandum by the Bailli of Troyes [Jean de Dinteville], summarised at Letters and Papers, Foreign and Domestic, of the Reign of Henry VIII, ed. J. S. Brewer et al., 21 vols, (London, Longman, 1862-1910, 1929-32; henceforth, LP), VI.1479, pp. 594-6, at p. 595. 
Henry meant well. When Thomas More was appointed chancellor, it was under a kind of safe-conduct for his conscience. Henry promised not to press him over the divorce, and More tiptoed delicately around treacherous ground. ${ }^{20}$ At first, he was nonetheless prominent in the king's counsels. A predominantly clerical group, a sort of spiritual council, was convened in spring 1530 to discuss issues arising from the spread of Lutheran and other heretical books. Henry and More were both present. ${ }^{21}$ A few months later, in November, a similar gathering was called upon to discuss the opinions on Henry's marriage secured from a number of European universities and to approve their redaction into a proclamation that was printed in December. ${ }^{22}$ After that, Henry began to lose patience, and was unable to honour his promise to More. It was More, as Chancellor, who was required to present the Determinations of the Universities to parliament in January 1531, and he made his disquiet subtly evident by delegating the task of actually reading out the text to Brian Tuke (whose several roles included that of parliamentary clerk). The Duke of Norfolk tried to flush him from cover by asking him to state his own view of the matter, but More dodged him deftly with the bland

${ }^{20}$ R. W. Chambers, Thomas More (London, Jonathan Cape, 1935), p. 237, citing both Roper's brief biography of More and a letter from More to Thomas Cromwell.

${ }^{21}$ Chapuys to Charles V, 10 May 1530, CSPSp, IV.i, 1529-30, no 302, pp. 530-6, at p. 532. For the proclamation, issued on 22 June 1530, see Tudor Royal Proclamations, ed. P. L. Hughes and J. F. Larkin, 3 vols (New Haven, Yale University Press, 1964-69), I, no. 129, pp. 193-7.

${ }^{22}$ For the session on the proclamation, see Scarpinello to the Duke of Milan, 2 and 16 December 1530, CSPV, IV, 1527-33, nos 637, pp. 266-8, at pp. 267-8; and 642, pp. 270-2, at p. 271. 
remark that he had already delivered his own view to the king in person. ${ }^{23}$ From this time, ambassadorial observations about the council and its membership rarely if ever mention More. A year later, he had decided that he could no longer in conscience hold office under the crown.

One of the most interesting aspects of the politics of the early 1530s is the apparent resurgence of that occasional and informal medieval institution, the 'great council', a larger gathering of nobles and notables that was somewhere between the ordinary royal council and a parliament. ${ }^{24}$ On more than one occasion, Chapuys reported gatherings of this kind. The first of them was in summer 1530, in the context of the 'spiritual council' that Henry convened to deal with heresy. The larger group, which included nobles and secular officials as well as bishops and theologians, was brought together to collect signatures for the famous letter of the realm of England to Pope Clement VII imploring him to grant Henry's divorce. The 85 signatories included both archbishops, two dukes and most of the secular peerage, along with assorted knights, courtiers and clergymen. ${ }^{25}$ The fact that only four other bishops signed not only confirms the report by Chapuys that those bishops known to support Catherine were not invited to attend but also shows that the episcopate was disproportionately

${ }^{23}$ For More's presentation of the opinions from the universities, see Chapuys to Charles V, 2 April 1531, LP, V.171, pp. 83-5, at p. 83. (The Calendar of State Papers Spanish for some reason does not give, as usual, the longer recensions of the despatches from Chapuys that are summarised under April 1531 in Letters and Papers.)

${ }^{24}$ For background on 'great councils', see P. J. Holmes, 'The Great Council in the Reign of Henry VII', English Historical Review, 101 (1986), 840-62.

${ }^{25}$ For the letter and its signatories, see http://ncronline.org/news/new-look-king-henry-viiiscomplicated-divorce (consulted 18 October 2014). For the meeting on Sunday 12 June, see Chapuys to Charles V, 15 June 1530, CSPSp, IV.i, 1529-30, no. 354, pp. 598-9. 
loyal to her. But the initiative was not an immediate success. Those men convened for the discussion raised difficulties, so that the meeting was adjourned, and, in the end, Henry's agents secured signatures by nobbling people one by one in their homes. ${ }^{26}$

Later that summer, another expanded council was convened. Once news had arrived of the decision in favour of Henry's divorce from the Sorbonne, the foremost theological faculty in Christendom, Henry gathered the council and a number of other lords at Hampton Court on 11 August, apparently in the hope that the news from Paris would sway those, such as More, who had hitherto opposed the divorce or maintained cautious neutrality. According to Chapuys, the French ambassadors who had brought the news from Paris were urging the king simply to go ahead and marry Anne, but, despite meeting the king daily for nearly a week, the council almost unanimously rejected the idea of unilateral action, insisting on the prior necessity of a papal annulment of the king's first marriage. ${ }^{27}$

Henry was not so easily deterred. October saw another session of a kind of 'spiritual council' at Hampton Court, with clergymen and lawyers brought together to discuss whether parliament could empower the archbishop of Canterbury to resolve the suit himself without reference to Rome. This looks like a response to the hesitations of the expanded king's council back in August. Henry's own position in the meantime was unshakeable. He let all and sundry know, in no uncertain terms, that there was no way his case was going to be heard or resolved outside England. But while he was happy to threaten a unilateral solution, he had as yet nothing like the necessary consensus among the political and ecclesiastical elites of England actually to go down that path. The real point of much of the conciliar activity of the

\footnotetext{
${ }^{26}$ Chapuys to Charles V, 15 June 1530, CSPSp, IV.i, 1529-30, no. 354, pp. 598-9; and also 20 June 1530, CSPSp, IV.i, 1529-30, no. 366, p. 616.

${ }^{27}$ Chapuys to Charles V, 20 August and 5 September 1530, CSPSp, IV.i, 1529-30, nos 411 and 422, pp. 689-92 and 708-10.
} 
early 1530s was not so much to seek good advice as to herd influential opinion towards the distant and difficult consensus that Henry needed to attain. The lawyers and theologians were no more easily stampeded than anyone else in 1530. If Chapuys is to be believed (and in this matter his report sounds plausible), they were asked whether parliament could empower the archbishop of Canterbury to hear the case by his own jurisdiction, and they said no. ${ }^{28}$

The conciliar gatherings of the early 1530s were not as amenable as Henry would have wished. In early summer 1531, he had several long sessions on the divorce with an expanded council that continued to see real differences of opinion voiced. The Earl of Shrewsbury spoke up strongly for the queen, and Henry Guildford, Controller of the Royal Household, was so disillusioned by events that he begged to resign his office rather than remain complicit in machinations against her. ${ }^{29}$ But such boldness was not to last. The purpose of these gatherings was not so much for the council to advise Henry as for Henry and his supporters to dragoon doubters into line, to shape and manage opinion at court and among the nobility. Soon afterwards, a heavyweight council delegation was sent to Catherine to try to bully her into accepting a hearing in England. She refused, and within a few weeks Henry had unceremoniously dumped her, parking her at Windsor during his customary summer 'gestes' while he went off instead with Anne Boleyn, never to see or speak to Catherine again. ${ }^{30} \mathrm{~A}$

${ }^{28}$ Chapuys to Charles V, 15 October 1530, CSPSp, IV.i, 1529-30, no. 460, pp. 758-62, at p. 758.

${ }^{29}$ Chapuys to Charles V, 6 June 1531, CSPSp, IV.ii, 1531-33, no. 739, pp. 169-78, with anecdotes from a number of recent conciliar gatherings involving up to 30 nobles (p. 171). See pp. 176-7 for Talbot, and 178 for Guildford. Chapuys was under the impression that Henry had been obliged to accept Guildford's resignation, but in fact the king persuaded Guildford to withdraw it.

${ }^{30}$ Chapuys to Charles V, 17 July 1531, CSPSp, IV.ii, 1531-33, no. 765, pp. 211-14, at p. 212. 
couple of weeks later, Henry had his council working overtime on a fierce rebuff to her plaintive requests for some explanation of the way she was now being treated. ${ }^{31}$ More than once over the next few years Catherine received conciliar delegations that sought to use the moral weight of the royal council to overwhelm her resistance to the royal will. In this mode, the council was more an instrument of that will than a bridle upon it. ${ }^{32}$

Perhaps the most important gathering of a 'great council' came in November 1533, when the whole king's council was reinforced with the chief justices and a good number of bishops and nobles in order to commence proceedings against the Holy Maid of Kent and to discuss the looming prospect that the pope would give judgement against Henry. The Maid - who just over a year before had herself been granted a personal audience with the king which was in its own way an occasion for counsel ${ }^{33}$ - had enjoyed considerable support from elements in the nobility, and this gathering was a way of breaking up that support, as she was brought before them to confess her fraudulence. The Chancellor, Thomas Audley, closed the proceedings with a speech along the same lines as a sermon that was preached against the

\footnotetext{
${ }^{31}$ Chapuys to Charles V, 31 July 1531, CSPSp, IV.ii, 1531-33, no. 775, pp. 222-7, at p. 223.

${ }^{32}$ See e.g. Chapuys to Charles V, 16 October 1531, CSPSp, IV.ii, 1531-33, no. 808, pp. 2636; and 16, 23 and 27 December 1533, CSPSp, IV.ii, 1531-33, nos. 1161 (pp. 881-6), 1164 (pp. 889-95), and 1165, pp. 895-902, esp. pp. 882-3 and 892.

${ }^{33}$ Chapuys to Charles V, 20 November 1533, CSPSp, IV.ii, 1531-33, no. 1153 (cf. LP, VI.1445), pp. 859-64, at p. 863, reports her appearance before Henry a year previously. According to Alan Neame, The Holy Maid of Kent (London, Hodder \& Stoughton, 1971), the Maid spoke with Henry on three separate occasions (pp. 118-19, 126-7, and 173-4).
} 
Maid a few days later during her public humiliation at Paul's Cross. ${ }^{34}$ It was probably this gathering too that approved the document against the Pope that was circulating in December under the title Articles Devisid by the Holle Consent of the Kynges Moste Honourable Counsayle, which paved the way for the Acts of Succession and Supremacy in 1534 by instructing Henry's people to accept the dissolution of his first marriage, and to pay no heed to any sanctions that might be issued by 'the byshop of Rome, by some men called Pope'. ${ }^{35}$ The consensus for which Henry had been working so long was beginning to take firm shape.

The activity of the council, though far from well-documented, can be detected indirectly. The business of counsel is still more obscure. But here and there evidence can be found of how Henry could be prevailed upon by counsel, at least when he was not already committed to a line of action. Hugh Latimer recalled advising Henry about the Holy Blood of Hailes, one of the most celebrated relics in medieval England: 'What ado there was to bring this out of the king's head! This great abomination, of the blood of Hayles, could not be taken a great while out of his mind. ${ }^{36}$ William Latymer tells how Henry, Anne and others (including Hugh

${ }^{34}$ Chapuys to Charles V, 20 November 1533, CSPSp, IV.ii, 1531-33, no. 1153 (cf. LP, VI.1445), pp. 859-64, for the council session; and 24 November 1533, no. 1154, pp. 864-8, at p. 866, for the sermon at Paul's Cross, which reprised Audley's speech.

${ }^{35}$ Articles Devisid by the Holle Consent of the Kynges Moste Honourable Counsayle (London, Berthelet, 1533, STC 9177), fo. 3v. Their publication is reported in Chapuys to Charles V, 9 December 1533, CSPSp, IV.ii, 1531-33, no. 1158, pp. 875-9, at p. 876 for the printing of material against the pope. See also John Hacket to Cromwell, 28 January 1534, $L P$, VII.115, pp. 45-6, for the circulation of a French translation in the Netherlands. ${ }^{36}$ H. Latimer, Sermons, ed. G. E. Corrie (Cambridge, Parker Society, 1844), p. 231. This relic, shown to pilgrims at Hailes Abbey, purported to be a quantity of the blood of Christ himself. 
Latimer) used to discuss religious issues during the royal progress in summer 1535, which took in Gloucestershire. ${ }^{37}$ He reports that 'hir highnes being throughly enformid [about the relic] never stayed, but made meanes to the king his majestie that this ydolatrous abuse might be taken awaye. And she optayned so that he caused the same ymediatly to be plucked downe $\ldots{ }^{38}$ If this story can be credited, then Henry's views towards this relic in particular, and perhaps also towards relics in general, underwent serious change in the mid-1530s as a result of arguments made in his presence by intimate and trusted spiritual advisers. Henry could be influenced by counsel.

There are plenty of indications that such conversations went on around the king's person in the 1530s and 1540s. In 1547, Stephen Gardiner reminded Thomas Cranmer of how, in Henry's days, he had argued in the Convocation House that while faith did not justify alone, 'faith only' justified - a delicate distinction which the 'King's Book' was brushing aside. Cranmer told the House that he would show his 'mynde to the King', and Gardiner further reminds him how Henry 'dyscussed yt thorowly and travailed in yt with you' until Cranmer graciously conceded. ${ }^{39}$ On another occasion, Gardiner recalled, Cranmer and he were with

${ }^{37}$ W. Latymer, 'A Chronicle of Anne Boleyn', ed. M. Dowling, Camden Miscellany XXX, Camden Society, 4th ser., 39 (1990), 23-65, at 62.

${ }^{38}$ Latymer, 'Chronicle of Anne Boleyn', 60-1. The relic was not destroyed until two years after Anne's execution, but the gist of the tale rings true. Latymer's story makes sense if we conjecture that by 'plucked downe' he simply meant that the relic was removed from public view.

${ }^{39}$ Gardiner to Cranmer, circa July 1547, in The Letters of Stephen Gardiner, ed. J. A. Muller (Cambridge, Cambridge University Press, 1933), pp. 316-61, at p. 336. The suggestion that Christians were saved by 'faith only' was a subtlety by which Protestant theologians sought to deflect one of the major criticisms that Catholics levelled against the doctrine usually 
the king at New Hall when the three of them discussed the place of images in worship, and Henry 'handled that matter at length, and discussed ... the understanding of Godes commaundment to the Jewes, so as all the clerkes in Christendome could not amend it' ${ }^{40}$ Looking back to the 1530s, he told of yet another occasion, at Hampton Court, when Cromwell 'put in the Kinges our late sovereigne lordes head to take upon him to have his will and pleasure regarded for a lawe', and sought to embarrass Gardiner by forcing him to give an opinion. 'Aunswer the King here ... but speake plainly and directly, and shrink not, man! Is not that ... that pleaseth the King, a lawe?' Gardiner wriggled away from the dilemma with some adroit flattery, invoking the old saying that while there were 'kings that had there will alwayes receaved for a lawe', Henry's way, namely, 'to make the lawes his wil, was more sure and quiet'. ${ }^{41}$ These recollections of Gardiner's were all penned during his rearguard

formulated as justification by 'faith alone', namely that it seemed to undervalue the importance of good deeds and charity in the economy of salvation. The response was that true faith was never 'alone', but was necessarily accompanied by charity and inevitably bore fruit in good deeds; but that nevertheless it was only faith - not charity or good deeds - that saved. ${ }^{40}$ Gardiner to the Duke of Somerset, 6 June 1547, Letters of Stephen Gardiner, pp. 286-95, at p. 290.

${ }^{41}$ Gardiner to Somerset, 14 October 1547, Letters of Stephen Gardiner, pp. 379-400, at p. 399. By Gardiner's account, Cromwell later 'turned cat in the panne afore company ... and charged me as though I had played his part'. Elton half seriously takes Cromwell's side in this, asking whether Gardiner might not himself be telling the story the wrong way round. See G. R. Elton, 'The Political Creed of Thomas Cromwell', in his Studies in Tudor and Stuart Politics and Government, 4 vols (Cambridge, Cambridge University Press, 1974-92), II, pp. 219-20, elaborating an argument to exculpate Cromwell from the imputation of 
action against the Protestant Reformation by royal injunction and proclamation that was under way in the first year of Edward VI's reign, and it would be hazardous to presume that they are accurate in every last detail. But to achieve even their rhetorical purpose they would have needed to be credible in their settings and circumstances, and thus they can be taken as providing an invaluable insight into the practical workings of counsel under Henry VIII.

Yet while Henry might be open to argument on some issues, on others his mind could close tighter than a trap. The perils of offering unwelcome counsel are evident from the crisis which led to Thomas More's resignation. This arose from the ill-judged response of the clergy to the Supplication against the Ordinaries that had been put together over the winter of 1531-2. The Supplication seems to have been largely the work of Thomas Cromwell, as he emerged from the political shadows into which he had been cast by Wolsey's fall. The clergy's response was drafted by Stephen Gardiner, who as the king's principal secretary should have been a leading figure in the king's counsels and was certainly prominent in formal conciliar activities in 1531. Had he had any idea where the Supplication was coming from and where it was headed, so shrewd a diplomat would surely have formulated a far more emollient response. But having been promoted bishop of Winchester in September 1531, and almost at once sent on a diplomatic mission to France, he was perhaps out of touch. On his return from France in March 1532 he helped compile a robust refutation of the tendentious special pleading put up against the clergy. It was not what the king wanted to hear. The imperial ambassador's despatch of 13 May 1532 (two days before Thomas More's resignation) reported Henry's anger at More and Gardiner. ${ }^{42}$ Before long, Cromwell had replaced Gardiner as Henry's principal secretary in all but name, and by autumn 1532 it was absolutism. But whichever way the conversation ran, it stands as an example of how counsel could be given.

${ }^{42}$ Chapuys to Charles V, 13 May 1532, CSPSp, IV.ii, 1531-33, no. 951, pp. 444-6, at p. 446. 
known as far away as Padua that Gardiner was so thoroughly out of favour that he was but rarely at court, and was therefore devoting himself to his diocesan duties. ${ }^{43}$

Concerns about the failure of counsel can be seen in the experience of another would-be councillor, Thomas Elyot, who arrived back in England early in 1532 as, in theory, a fullyfledged member of the king's council. ${ }^{44}$ Having been resident at the court of Charles V for a couple of years, he could be forgiven for imagining that his insights into imperial policy might be of some value to a king proposing to break his matrimonial ties to the emperor. Elyot, like much of the English nobility and gentry, was anti-French and therefore proBurgundian and pro-Imperial, and had aligned himself with Imperial interests during his sojourn abroad. On his return he entered into immediate and intimate communication with his opposite number, Eustace Chapuys, who eagerly reported to Charles that Elyot was striving to give Henry salutary counsel. ${ }^{45}$ If, as I have proposed elsewhere, an anonymous anti-

${ }^{43}$ Thomas Winter to Runcorne, Padua, 20 October 1532, LP, V.1453, p. 614. ${ }^{44}$ Ambassadors were sworn of the council before they left the realm, and letters of credence routinely describe them as councillors. See e.g. letters of credence for Nicholas Hawkins, 27 and 30 September and 1 October 1532, in Records of the Reformation, ed. Pocock, II, 324-5 and 326-7. Dunham remarks that 'Men who went as ambassadors ... came to council meetings when they were in England' ('Henry VIII's Whole Council, 1509-1527', 198). ${ }^{45}$ Chapuys to Charles V, 5 June 1532, CSPSp, IV.ii, 1531-33, no. 957, p. 453. For further comment on Elyot's return in 1532, see G. Walker, Writing under Tyranny (Oxford, Oxford University Press, 2005), pp. 123-5. 
divorce tract published in 1532 is indeed to be attributed to Elyot, then his counsel would have been far from welcome. ${ }^{46}$

Certainly Elyot was rapidly disillusioned with Henry's attitude, and gave voice to this sentiment in his satirical dialogue Pasquil the Playne, published anonymously in spring 1533. ${ }^{47}$ The eponymous Pasquil falls into conversation with two royal councillors on their way to court, Gnatho and Harpocrates. Their names - the former derived from the Greek for 'jaw', and the latter the name of a classical god of silence - seem to suggest that they represent opposing deviations from an Aristotelian golden mean of true counsel. As F. W. Conrad has convincingly argued, Harpocrates, who is described as 'my lordes confessour', is obviously meant for John Longland, Henry's confessor and Bishop of Lincoln, who was widely though erroneously credited with having sown in the king's mind the seed of that

\footnotetext{
${ }^{46}$ Non esse neque Divino neque Numano Iure Prohibitum ('Luneburg' [Antwerp], [Martin de Keyser], 1532). See R. Rex, The Theology of John Fisher (Cambridge, Cambridge University Press, 1991), p. 179.

${ }^{47}$ The somewhat overstated paper by A. Walzer, 'Rhetoric of Counsel in Thomas Elyot's Pasquil the Playne', Rhetorica, 30 (2012), 1-21, claims to challenge the 'standard approach' to this text that sees it 'as a product of Elyot's disillusionment' (4). But the target actually struck - the idea that Pasquil himself represents 'Elyot's preferred style of counsel' (5) - is not the same thing at all, and may be a 'straw man': it is hard to credit the notion that Elyot thought Pasquil's plainness appropriate to a diplomat or a councillor. It is equally implausible to posit that an author as subtle as Elyot did not intend his dialogue to have topical political resonance. It is a critique of Henrician counsel, though its rhetorical skill and second-edition amendments served to insulate its author from serious repercussions.
} 
conscientious scruple about his marriage to Catherine. ${ }^{48}$ Gnatho is harder to identify, but is most likely Robert Barnes, the renegade Austin Friar turned Lutheran who had fled to Wittenberg in the late 1520s, but briefly returned to England over Christmas 1531-2, in order to discuss the Lutheran position on the king's divorce. ${ }^{49}$ In conversation, Gnatho and

${ }^{48}$ Conrad, 'The Problem of Counsel Reconsidered', pp. 98-9. He reckons it particularly revealing that the description of Harpocrates as confessor to his lord is dropped in the second edition. See Pasquil the Playne (London, Thomas Berthelet, 1533, STC 7672), fo. 13v (compare the second edition, STC 7672.5, fo. 14r). In an illuminating analysis of Pasquil, Walker (Writing under Tyranny, pp. 181-95) identifies Harpocrates with Cranmer (p. 185), noting but not engaging with Conrad's identification in a footnote (p. 484, n. 7). But Longland was at that very time Henry's confessor, a position Cranmer never held. Warner sees the otherwise curious fact that Pasquil was issued by the king's printer (Berthelet) as further evidence of the king's desire to appear in public as a well counselled king (Henry VIII's Divorce, pp. 73-4).

${ }^{49}$ Chapuys to Charles V, 21 December 1531, CSPSp, IV.ii, 1531-33, no. 865, pp. 337-8, at p. 338, notes the return to England of an exiled Austin Friar who had spent time with Luther. That is Barnes. The identification of Gnatho proposed here rests on the grounds that he is described as a man of 'profession', which then mostly meant a professed member of a religious order; and that, while clutching a New Testament, he is also concealing within his garish secular clothing a copy of Chaucer's Troilus and Cressyde (Pasquil, fos 3v-4r, for his books and clothing; and '9'v [i.e. 6v], 'perdie hit agreeth not with your profession to be out of charitie'). See Thomas More, A Confutation of Tyndale's Answer, ed. L. A. Schuster et al., 3 vols, The Complete Works of St. Thomas More, 8 (New Haven, Yale University Press, 1973), pp. 845, 885 and 896 for details of Barnes's visit, including a specific comment on his showy clothing and a knowing insinuation of impropriety with the landlady of his lodgings 
Harpocrates are induced by Pasquil to betray their true characters before hastening away to court. All three speakers make comments that cast helpful light on Henrician counsel. Gnatho taunts Pasquil as one who is 'not yet called to counsaile' (11r), advising him that he might get on better if he spent more time reading the New Testament (Pasquil has already shown his hand as a Catholic worried by events in Germany, 9r-v). This tells us something about Elyot's views of what was in favour at court, while Pasquil's blunt disparagement of 'dumme counsailours' who 'do not theyr office, wherfore they be called to counsayll' (29r) shows the same sort of concern for the king's conscience and good name as was urged by Stephen Baron at the start of the reign. ${ }^{50}$ The most telling of all Pasquil's remarks, though, is this: 'Tushe men, my playnnes is so well knowen / that I shall neuer come vnto priuie chamber or galerie' $(29 \mathrm{v})$. The unselfconscious assumption that counsel is not a matter for the council table but for more intimate and informal contexts tells us where we need to look to see counsel in action, and explains why it is so hard to find written evidence of it.

The delicate relationship between conscience and counsel was acted out in a curious charade at court in March 1533, when chaplains of Henry's and Anne's both preached in the same week against his first marriage, decrying it as incest and urging his council to persuade him to terminate it. ${ }^{51}$ Everyone here was playing their part perfectly: the preachers through

on Paul's Wharf (possibly explaining the faintly sexualised allusion to Troilus). On Barnes's visit to England see K. D. Maas, The Reformation and Robert Barnes: History, Theology and Polemic in Early Modern England (Woodbridge, Boydell, 2010), pp. 25-6.

${ }^{50}$ See above, at note 1 .

${ }^{51}$ Chapuys to Charles V, 15 March 1533, CSPSp, IV.iii, 1531-33, no. 1056, pp. 618-24, at p. 618. Chapuys does not specify which chaplain called upon Henry's councillors to intervene. (The preachers are said to have described his marriage to Catherine as 'adultery', but that 
teaching the truth, the advisers through emphasising to the king his duty and the king by duly attending to them all. This would have been a little more plausible had it not so obviously constituted an ironic comment on a similar episode a year before. On Easter Sunday 1532, the Father Provincial of the Observant Franciscans, William Peto, had roundly rebuked Henry to his face in a sermon in the Greenwich friary church, next door to the royal palace. He had boldly proclaimed that the 'excessive affection' of monarchs, exacerbated by 'false counsellors', shut their ears against the truth, a blunt accusation of the failure of counsel. Henry managed to keep his temper enough to discuss it with him afterwards, but then took advantage of Peto's departure overseas to put up one of his chaplains to preach a sermon in favour of the divorce from the same pulpit the following week. On his return, Peto objected to this, but tensions increased (not least because he had gone abroad not, as he claimed, to attend a general chapter of his order at Toulouse, but to publish a book against the divorce!) to such an extent that he left the country again, for an exile that was to last twenty years. ${ }^{52}$

The increasing risks of frank counsel are illustrated in the differing fates of Cuthbert Tunstall (Bishop of Durham) and his secretary (and cousin), Dr Robert Ridley, in spring 1534. Ridley had spoken out robustly against Henry at the divorce tribunal in 1529, and had signed a protest against the concession to Henry of the title 'Supreme Head' early in 1531. His episcopal patron wrote to Henry in 1531 questioning that title, and eliciting from the king the assurance that it was purely temporal in scope, and in 1533 opposed moves for the

makes no sense. Either Chapuys or his informant or the calendar is garbling or bowdlerising. Henry was adamant by this time that his intimacy with Catherine had been incest.) ${ }^{52}$ Chapuys to Charles V, 16 April 1532, CSPSp, IV.ii, 1531-33, no. 934, gives edited highlights of Peto's sermon and relates some of its aftermath. For Peto, see the entry by T. F. Mayer in the $O D N B$. 
divorce at the Northern Convocation. ${ }^{53}$ Both men, therefore, had made their feelings abundantly clear. At the height of tension in spring 1534, shortly after the passing of laws for the submission of the clergy and the succession to the crown, and while the oath to the new succession was being exacted, Tunstall's residences were raided and searched. ${ }^{54}$ A rumour spread overseas that he had been gaoled along with Fisher and More; in fact he became a loyal spokesman for the regime. But the rumour was not groundless, for his secretary certainly was arrested. ${ }^{55}$ When Chapuys reported on the session of the council to which he

\footnotetext{
${ }^{53}$ For Tunstall's protest in 1531, and the king's response, see LP, V.819-20. For Ridley's outburst at the matrimonial tribunal in summer 1529 see George Cavendish, The Life and
} Death of Cardinal Wolsey, ed. R. S. Sylvester, Early English Text Society, orig. ser., no. 243 (London, Oxford University Press, 1959), p. 86. For Ridley’s signature to the Canterbury Convocation's protest, see P. Friedmann, Anne Boleyn: A Chapter of English History, 15271536, 2 vols (London, Macmillan, 1884), I, 142, n. 2.

${ }^{54}$ For these bills in parliament see Chapuys to Charles V, 7 March 1534, 25 March 1534 and 30 March 1534, CSPSp, V.i, 1534-35, nos. 22, pp. 72-6; 31, pp. 91-5; and 32, pp. 95-7. For the raids on Tunstall's residences in County Durham, see John ap Rice to Cromwell, from Stockton on Tees, 2 May 1534, TNA, SP 1/70, fo. 6 [LP, V.987, miscalendared under 1532]. ${ }^{55}$ For Robert Ridley, see the entry by Richard Rex in the $O D N B$. The German Catholic controversialist Johannes Cochlaeus reported in a letter of 28 October 1534 from Dresden that Fisher and More had been incarcerated, along with 'Robertus Ridleius summus theologus'. See W. Friedensburg, 'Beiträge zum Briefwechsel der katholischen Gelehrten Deutschlands im Reformationszeitalter', Zeitschrift für Kirchengeschichte, 18 (1898), 23397, at 261. The Spanish humanist Juan Luis Vives told Erasmus earlier that year that Fisher and More had been arrested with the Bishop of London. He almost certainly meant Tunstall, the former bishop of London (rather than his successor, Stokesley, whose promotion rested 
was summoned on Saturday 16 May 1534, to be treated to a lengthy harangue in defence of the divorce delivered by Edward Foxe, he listed those present, including Tunstall. But Tunstall, he observed in passing, had conformed only after the searches of his residences, and had been forbidden from attending parliament while the succession was being debated. Indeed, he inferred that the only purpose of this charade was to make sure he (Chapuys) knew that both Edward Lee and Cuthbert Tunstall had now fully come round to Henry's way of thinking. ${ }^{56}$

Councils and counsel were prominent in the politics of the early 1530s. Henry knew the theory of counsel, and genuinely seems to have sought to live out that theory in practice. Yet, as we have noted, whether ordinary, great or privy, Henry's councils reflected the theory of counsel without always embodying its practice. The Duke of Norfolk's observation in 1530 that God alone could change the king's mind about his marriage is an inadvertent comment

on his support for the divorce); and this was presumably a further confusion on top of that between the bishop and his secretary. See Vives to Erasmus, 10 May 1534, in Opus epistolarum Des. Erasmi Roterodami, ed. P. S. Allen, 12 vols (Oxford, Clarendon, 1906-58), X, ep. 2932, pp. 383-4: 'Capti sunt ... in Britannia Episcopus Roffensis et Londinensis, et Thomas Morus'.

${ }^{56}$ Chapuys to Charles V, 19 May 1534, CSPSp, V.i, 1534-35, no. 58, pp. 155-66, at p. 164. Those listed as present (p. 156) were: the archbishops of Canterbury and York; Norfolk, Exeter and Wiltshire; Cromwell, the Chancellor (Audley), the Controller of the Household (William Paulet) and the Captain of the Guard; the chief judges; and Foxe, Goodrich, Sampson, Stokesley and Tunstall. Chapuys notes the raids on Tunstall's residences (p. 159). 
on the limits of Henrician counsel. ${ }^{57}$ The emerging doctrine of the royal supremacy did not help, as it postulated a special relationship between the monarch and his creator. The claim that the heart of the king was in the hands of God (Proverbs 21:1, 'cor regis in manu domini’), which was among many biblical texts invoked to support the royal supremacy, ${ }^{58}$ evidently underlies Henry's instructions to William Paget for his diplomatic mission to Germany in early 1534 , which described the king's great matter as 'being fully examined and resolved in his own conscience', and which added that 'the same court of his conscience' was 'enlightened and instructed by the Spirit of God, who possesses and directs the hearts of princes ${ }^{59}$ Once, thanks to the doctrine of the royal supremacy, Henry had recruited to his council no less able and obliging an adviser than the Holy Spirit, the dynamics between him and his other advisers would necessarily change. The advice he received from mere men might play its part in God's plan for his conscience. But given the guidance that scripture guaranteed him, it is hardly surprising that he expected others to conform their consciences to his. Counsel and councils provided a means by which this might be brought about. His favourite spiritual adviser, Thomas Cranmer, exemplified this perfectly in the two episodes that Stephen Gardiner preserved for posterity. We can hardly credit the notion that Cranmer was genuinely convinced by his sovereign's cheap and cheerful theology on faith and images. But Cranmer realised one thing very clearly: there was room for only one conscience in

${ }^{57}$ Chapuys to Charles V, 12 January 1530, CSPSp, IV.i, 1529-30, no. 249, pp. 414-20, at p. 417. The contrast between the rhetoric of counsel and the reality of tyranny is emphasised by Davies, 'Cromwellian Decade' and Walker, Writing under Tyranny. ${ }^{58}$ See e.g. Christopher St German, A Treatyse concerninge the Power of the Clergye (London, Thomas Godfrey, n.d. [c.1534], STC 21588), sig. A4v, 'As diuisyons of waters are in the handes of our lorde / so is the herte of a kynge in the hande of our lorde'. ${ }^{59}$ LP, VII.148, Instructions for William Paget: BL, Cotton MS Vit. B.xiv.68. 
Henry VIII's church. That meant that counsellors had to tread very carefully in order not to overstep the limits of traditional conciliar 'free speech' when their sovereign's conscience, or interest, was too firmly engaged. Counsel under such conditions could neither win him the love of his subjects nor leave his good name and conscience intact. 